\section{Dipping Bedding Plant Liners in Paclobutrazol or Uniconazole Inhibits Subsequent Stem Extension}

\author{
Matthew G. Blanchard ${ }^{1}$ and Erik S. Runkle ${ }^{2,3}$
}

AdDitional index words. Argyranthemum, Calibrachoa, growth retardant, Petunia, Scaevola, Verbena

SUMMARY. An increasingly popular technique for applying plant growth regulators (PGRs) to floriculture crops is to dip or soak the root medium of a transplant in a chemical solution before transplanting. This PGR application method, termed a "liner dip," can be an effective height-control strategy for greenhouse crop production. However, few studies have quantified how bedding plant species respond to different chemicals and application rates. Argyranthemum (Argyranthemum $\times$ bybrida 'Sunlight'), calibrachoa (Calibrachoa $\times$ bybrida 'Callie Dark Blue'), petunia (Petunia $\times$ bybrida 'Cascadias Vivid Red'), scaevola (Scaevola albida 'Jacob's White'), and verbena (Verbena $\times$ bybrida 'Rapunzel Red') liners were dipped in paclobutrazol at 4,8 , or $16 \mathrm{mg} \cdot \mathrm{L}^{-1}$ or in uniconazole at 2,4 , or $8 \mathrm{mg} \cdot \mathrm{L}^{-1}$ for 30 seconds and subsequently transplanted into 4.5 -inch-diameter round pots. At 28 days after transplant, all rates of paclobutrazol and uniconazole inhibited subsequent stem elongation by $21 \%$ to $67 \%$ in calibrachoa, petunia, scaevola, and verbena. In argyranthemum, stems were $33 \%$ to $42 \%$ shorter in plants treated with paclobutrazol at 8 or $16 \mathrm{mg} \cdot \mathrm{L}^{-1}$ or uniconazole at all rates. In some species, the liner dip delayed flowering and reduced flower number compared with that of nontreated plants. This pretransplant PGR application technique can be useful on vigorous ornamental species when grown together in the same container with less aggressive species without a PGR application.

C ontrolling height of bedding plants can be one of the most difficult challenges for commercial greenhouse growers. Plant growth regulators (PGRs) often are used to inhibit stem elongation and to limit final plant height. Several techniques are commonly used to apply growth-regulating chemicals, including a foliar spray, a substrate drench, or a combination of both (i.e., sprench) (Barrett, 1999). For bulbous crops, such as hyacinth (Hyacinthus orientalis) or 'Star Gazer' oriental lily (Lilium hybrids), a preplanting bulb soak in a PGR solution is an effective height-control strategy (Krug et al., 2005, 2006). An application method that has become increasingly popular among commercial growers is to dip or soak the root

Department of Horticulture, Michigan State University, A288 Plant and Soil Sciences Building, East Lansing, MI 48824

We thank Fine Americas Inc., the Western Michigan Greenhouse Association, the Metropolitan Detroit Flower Growers Association, and Raker's Acres for their contributions to this project. We also thank Mike Olrich for his greenhouse assistance.

${ }^{1}$ Graduate student.

${ }^{2}$ Assistant professor and extension specialist.

${ }^{3}$ Corresponding author. E-mail: runkleer@msu.edu medium of a transplant in a chemical solution before transplanting (Schnelle et al., 2005). This PGR application method is termed a "liner dip" or "liner soak" (Schnelle et al., 2005). Advantages of a liner dip include ease of application, effectiveness in controlling stem elongation of aggressive species, ability to treat a large number of plants before transplanting into a final container, and reduced chemical runoff during application. In addition, a liner dip can be an effective application method when using chemicals such as paclobutrazol or uniconazole, which are absorbed by roots and transported in the xylem (Davis et al., 1988).

A pretransplant liner dip has been reported to inhibit stem elongation in potted plants and herbaceous perennials. In poinsettia (Euphorbia pulcherrima), soaking foam strips in a solution of uniconazole at $1.0 \mathrm{mg} \cdot \mathrm{L}^{-1}$ for 15 min before transplanting suppressed plant height by $55 \%$ compared with that of nontreated plants (Bearce and Singha, 1992). Latimer and Groover (2005) reported that Russian sage (Perovskia atriplicifolia) liners dipped in a solution of paclobutrazol at $2.0 \mathrm{mg} \cdot \mathrm{L}^{-1}$ or uniconazole at $1.0 \mathrm{mg} \cdot \mathrm{L}^{-1}$ for $15 \mathrm{~min}$ before transplant were $26 \%$ or $35 \%$ shorter than nontreated plants respectively at 5 weeks after application. These studies indicate that greenhouse growers can use a PGR liner dip to control the height of some greenhouse crops. However, more research information is needed to determine the response of other species to different chemicals and application rates. The objective of this study was to determine the effects of a pretransplant liner dip application of paclobutrazol and uniconazole on five common species of bedding plants.

\section{Materials and methods}

Plant material. On 3 Mar. 2005 , rooted vegetative cuttings of argyranthemum 'Sunlight', calibrachoa 'Callie Dark Blue', petunia 'Cascadias Vivid Red', scaevola 'Jacob's White', and verbena 'Rapunzel Red' grown in liners [50-cell size $(3.8 \times$ $2.5 \mathrm{~cm})]$ and in a peat-based medium were received in East Lansing, Mich., from a commercial greenhouse (Raker's Acres, Litchfield, Mich.). Plants were subsequently grown at $20{ }^{\circ} \mathrm{C}$ under a 9 -h photoperiod maintained by pulling opaque black cloth from 0800 to $1700 \mathrm{HR}$. All plants were pinched to three or four nodes $7 \mathrm{~d}$ before the chemical application.

Chemical applications. Plants were irrigated on the day preceding the application. On 14 Mar., each liner tray was cut into sections containing 10 plants. Each 10 -cell section was then placed into a tray

\begin{tabular}{llll}
\hline $\begin{array}{l}\text { Units } \\
\begin{array}{l}\text { To convert } \\
\text { U.S. to SI, multiply by }\end{array}\end{array}$ & U.S. unit & SI unit & $\begin{array}{l}\text { To convert SI } \\
\text { to U.S., multiply by }\end{array}$ \\
\hline 29.5735 & $\mathrm{fl} \mathrm{oz}$ & $\mathrm{mL}$ & 0.0338 \\
2.5400 & inch $(\mathrm{es})$ & $\mathrm{cm}$ & 0.3937 \\
1 & $\mathrm{ppm}$ & $\mathrm{mg} \cdot \mathrm{L}^{-1}$ & 1 \\
$\left({ }^{\circ} \mathrm{F}-32\right) \div 1.8$ & ${ }^{\circ} \mathrm{F}$ & ${ }^{\circ} \mathrm{C}$ & $\left(1.8 \times{ }^{\circ} \mathrm{C}\right)+32$
\end{tabular}


containing $2.5 \mathrm{~cm}$ paclobutrazol (Piccolo; Fine Americas, Walnut Creek, Calif.) at 4,8 , or $16 \mathrm{mg} \cdot \mathrm{L}^{-1}$ or uniconazole (Sumagic; Valent USA Corp., Marysville, Ohio) at 2, 4 , or $8 \mathrm{mg} \cdot \mathrm{L}^{-1}$ for $30 \mathrm{~s}$. Ten plants of each species that did not receive a chemical application were designated as the control. The chemical applications were made between 1100 and $1200 \mathrm{HR}$ and were performed in a glass-glazed greenhouse. The average air temperature during the application was $20.6{ }^{\circ} \mathrm{C}$ and the maximum photosynthetic photon flux $(P P F)$ was $700 \mu \mathrm{mol} \cdot \mathrm{m}^{-2} \cdot \mathrm{s}^{-1}$. After the chemical application, liners were placed on a greenhouse bench for $3 \mathrm{~h}$ and then plants were subsequently transplanted into 4.5-inch-diameter round plastic pots (volume, $591 \mathrm{~mL}$ ) containing a commercial soilless medium (Suremix; Michigan Grower Products, Galesburg, Mich.).

GreEnhouse ENVIRONMENT. Plants were grown at a constant temperature set point of $20^{\circ} \mathrm{C}$ in a glassglazed greenhouse with exterior whitewash. The actual average daily temperature during the experiment was $20.1 \pm 2.6^{\circ} \mathrm{C}$, as measured by aspirated thermocouples and recorded by a CRI0 data logger (Campbell Scientific, Logan, Utah). Natural photoperiods were extended to a $16-\mathrm{h}$ photoperiod (0600 to $2200 \mathrm{HR}$ ) by high-pressure sodium lamps that delivered a $P P F$ of 25 to $50 \mu \mathrm{mol} \cdot \mathrm{m}^{-2} \cdot \mathrm{s}^{-1}$ at plant height [as measured with a line quantum sensor (Apogee Instruments, Logan, Utah)]. Plants were irrigated as necessary with reverse osmosis water supplemented with a water-soluble fertilizer at each irrigation providing $125 \mathrm{mg} \cdot \mathrm{L}^{-1} \mathrm{~N}$, $12 \mathrm{mg} \cdot \mathrm{L}^{-1} \mathrm{P}, 100 \mathrm{mg} \cdot \mathrm{L}^{-1} \mathrm{~K}, 65 \mathrm{mg} \cdot \mathrm{L}^{-1}$ $\mathrm{Ca}, 12 \mathrm{mg} \cdot \mathrm{L}^{-1} \mathrm{Mg}, 1.0 \mathrm{mg} \cdot \mathrm{L}^{-1} \mathrm{Fe}$ and $\mathrm{Cu}, 0.5 \mathrm{mg} \cdot \mathrm{L}^{-1} \mathrm{Mn}$ and $\mathrm{Zn}, 0.3$ $\mathrm{mg} \cdot \mathrm{L}^{-1} \mathrm{~B}$, and $0.1 \mathrm{mg} \cdot \mathrm{L}^{-1} \mathrm{Mo}($ GreenCare Fertilizers, Kankakee, Ill.).

DAta COLlection AND ANALYSIS. Total plant height (from the medium surface to the tip of the longest extended stem) was measured on the day of application and at $28 \mathrm{~d}$ after application. Height increase and height inhibition percentage compared with that of control plants were calculated. Date of first flowering (open flower) was recorded for each plant, and time to flower was calculated. On the day that each plant flowered, the total number of flower buds was counted and the average was calculated for each treatment.

A completely randomized design was used. Data were analyzed using an SAS (SAS Institute, Cary, N.C.) mixed model procedure (PROC MIXED), and pairwise comparisons between treatments were performed using Tukey's honestly significant difference (HSD) test at $P \leq 0.05$. An exponential decay model was fitted to data for height increase as a function of chemical rate using SigmaPlot v. 8.02 (SPSS, Chicago).

\section{Results and discussion}

Argyranthemum. Plant height increase of 'Sunlight' displayed an exponential decay response $\left(r^{2}=\right.$ 0.65 and 0.73 ) as the rate of paclobutrazol or uniconazole liner dip increased (Fig. 1A, B). At 28 d after application, stems were 2.9 to $4.4 \mathrm{~cm}$ shorter in plants treated with paclobutrazol at 8 or $16 \mathrm{mg} \cdot \mathrm{L}^{-1}$ or with uniconazole at all rates tested. Stem elongation in plants treated with paclobutrazol at $4 \mathrm{mg} \cdot \mathrm{L}^{-1}$ was not statistically different from that of control plants. Paclobutrazol at $16 \mathrm{mg} \cdot \mathrm{L}^{-1}$ and uniconazole at $8 \mathrm{mg} \cdot \mathrm{L}^{-1}$ suppressed final plant height by $36 \%$ and $42 \%$ respectively. The effectiveness of uniconazole on controlling stem elongation of argyranthemum is in agreement with data from Gibson et al. (2003), who reported that a foliar spray of $40 \mathrm{mg} \cdot \mathrm{L}^{-1}$ inhibited plant height by $25 \%$ at $22 \mathrm{~d}$ after application.

Plants treated with paclobutrazol at $16 \mathrm{mg} \cdot \mathrm{L}^{-1}$ or uniconazole at all rates flowered 9 or $10 \mathrm{~d}$ later than untreated plants (Table 1). Time to flower in plants treated with paclobutrazol at 4 or $8 \mathrm{mg} \cdot \mathrm{L}^{-1}$ was not significantly different from that of control plants and ranged from 37 to $43 \mathrm{~d}$. The total number of flower buds ranged from 34 to 46 and was not significantly different among treatments.

Calibrachoa. The stem elongation response of 'Callie Dark Blue' to paclobutrazol or uniconazole was fit to an exponential decay model with an $r^{2}$ value of 0.82 or 0.78 respectively (Fig. 1C, D). Total stem elongation after $28 \mathrm{~d}$ was increasingly inhibited as the rate of either chemical increased. Paclobutrazol at 8 and $16 \mathrm{mg} \cdot \mathrm{L}^{-1}$ or uniconazole at $8 \mathrm{mg} \cdot \mathrm{L}^{-1}$ suppressed plant height by $56 \%, 64 \%$, and $67 \%$ respectively. The highest application rate of both chemicals continued to inhibit stem elongation $49 \mathrm{~d}$ after application (data not presented).

Flowering time was not significantly different among any of the treatments and ranged from 29 to 33 d (Table 1). However, plants treated with paclobutrazol or uniconazole at the highest rates $\left(16 \mathrm{mg} \cdot \mathrm{L}^{-1}\right.$ or $8 \mathrm{mg} \cdot \mathrm{L}^{-1}$ respectively) had, on average, 20 fewer flower buds compared with untreated plants, but we believe plants were still of acceptable commercial quality.

Petunia. Stem length of 'Cascadias Vivid Red' at $28 \mathrm{~d}$ after application decreased as the concentration of paclobutrazol and uniconazole increased, and data were fit to an exponential decay model with an $r^{2}$ value of 0.61 or 0.60 respectively (Fig. 1E, F). The subsequent height increase of liners dipped in paclobutrazol or uniconazole was 3.2 to $6.0 \mathrm{~cm}(27 \%$ to $51 \%)$ less than that of untreated plants.

Plants dipped in paclobutrazol at $16 \mathrm{mg} \cdot \mathrm{L}^{-1}$ flowered, on average, $6 \mathrm{~d}$ later than untreated plants (Table 1 ). Time to flower for plants dipped in uniconazole was similar to that of untreated plants and averaged $24 \mathrm{~d}$. Plants treated with paclobutrazol at 8 or $16 \mathrm{mg} \cdot \mathrm{L}^{-1}$ or uniconazole at all rates had, on average, 5 to 10 fewer flower buds compared with control plants. However, we believe that plants were still of acceptable commercial quality.

Scaevola. The stem elongation response of 'Jacob's White' to increasing concentrations of paclobutrazol or uniconazole was fit to an exponential decay model with an $r^{2}$ value of 0.73 or 0.55 respectively (Fig. 1G, H). At $28 \mathrm{~d}$ after application, the dip in paclobutrazol or uniconazole suppressed subsequent stem elongation by 4.2 to $10.2 \mathrm{~cm}$. Paclobutrazol or uniconazole applied at the highest rates ( 16 and $8 \mathrm{mg} \cdot \mathrm{L}^{-1}$ respectively) were judged to have caused excessive inhibition of stem elongation. For example, paclobutrazol at $16 \mathrm{mg} \cdot \mathrm{L}^{-1}$ inhibited plant height increase by $66 \%$ compared with that of untreated plants. At $49 \mathrm{~d}$ after application, plants treated at these high rates remained excessively compact, and we believe that they were not marketable (data not presented). In 'Blue Wonder' scaevola, a medium 


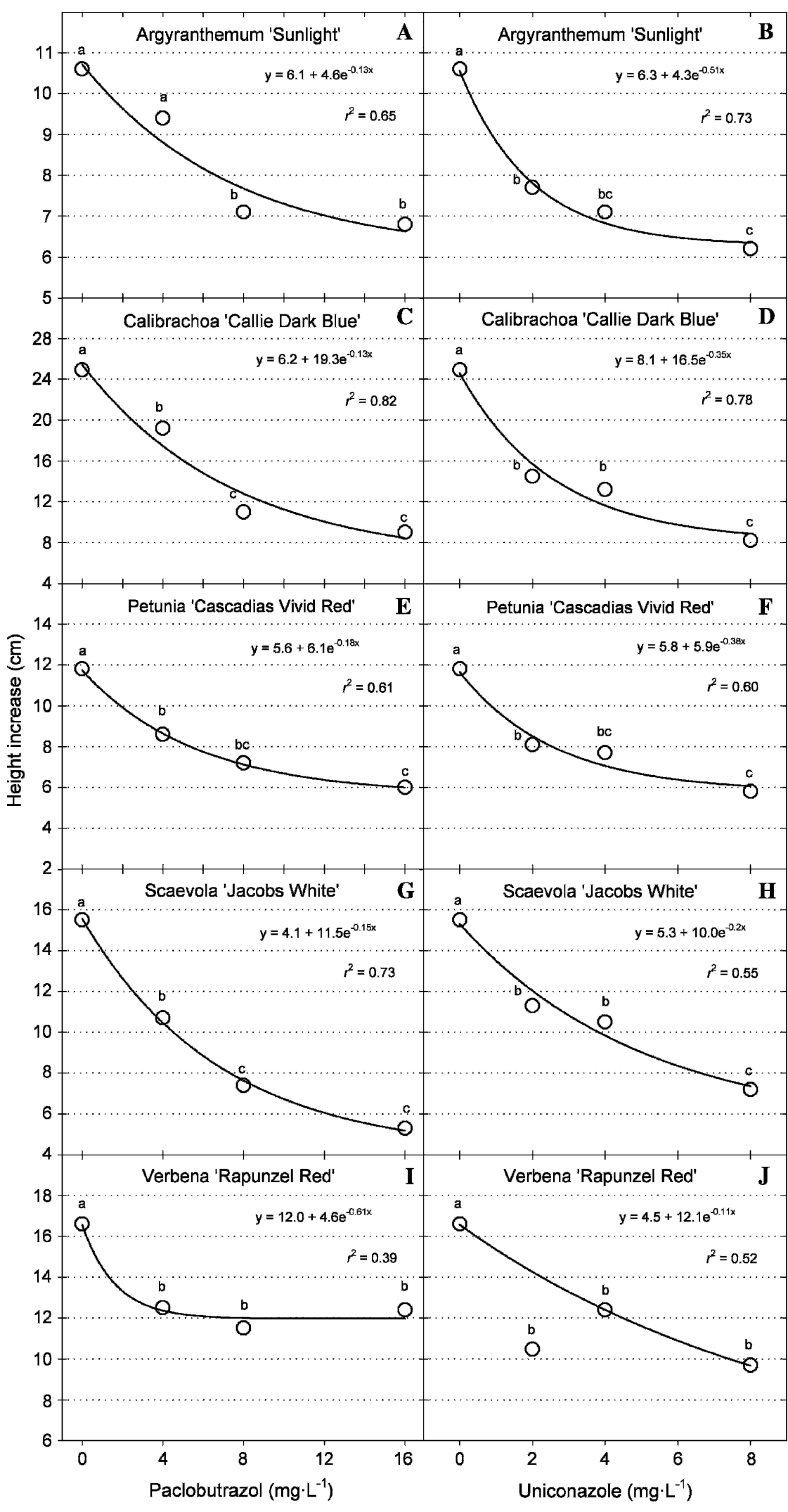

Fig. 1. Effects of paclobutrazol and uniconazole liner dips on stem extension measured $28 \mathrm{~d}$ after application in five bedding plant species. Mean separation within each species and chemical by Tukey's honestly significant difference test at $P \leq \mathbf{0 . 0 5}$. Regression lines were generated from an exponential decay model, and each symbol represents the mean of 10 plants. Values for $R^{2}$ are based on data for the entire population. Data at $2 \mathrm{mg} \cdot \mathrm{L}^{-1}$ for panel $\mathrm{J}$ were not included in the regression analysis $\left(1 \mathrm{mg} \cdot \mathrm{L}^{-1}=1 \mathrm{ppm} ; 1 \mathrm{~cm}=0.3937 \mathrm{inch}\right)$. drench of paclobutrazol at $4 \mathrm{mg} \cdot \mathrm{L}^{-1}$ or uniconazole at $1 \mathrm{mg} \cdot \mathrm{L}^{-1}(120 \mathrm{~mL} /$ 10-cm-diameter pot) suppressed final plant width by $42 \%$ or $29 \%$ respectively (Starman and Williams, 2000).

Paclobutrazol at 8 or $16 \mathrm{mg} \cdot \mathrm{L}^{-1}$ or uniconazole at $8 \mathrm{mg} \cdot \mathrm{L}^{-1}$ delayed flowering by an average of $12 \mathrm{~d}$ compared with that of untreated plants (Table 1). Liners dipped in uniconazole at $8 \mathrm{mg} \cdot \mathrm{L}^{-1}$ had 33 fewer flower buds than control plants. Therefore, rates of uniconazole greater than $4 \mathrm{mg} \cdot \mathrm{L}^{-1}$ can compromise plant quality and are not recommended under the growing conditions provided in this experiment.

Verbena. Stem length of 'Rapunzel Red' was increasingly inhibited (by $25 \%$ to $42 \%$ ) as the concentration of the paclobutrazol or uniconazole dip increased (Fig. II, J). The stem elongation response to increasing concentrations of paclobutrazol or uniconazole was fit to an exponential decay model with an $r^{2}$ value of 0.39 or 0.52 respectively. The inconsistent stem elongation response of 'Rapunzel Red' to $2 \mathrm{mg} \cdot \mathrm{L}^{-1}$ uniconazole compared with 0 and $4 \mathrm{mg} \cdot \mathrm{L}^{-1}$ uniconazole is unclear. Therefore, data for height increase in plants treated with $2 \mathrm{mg} \cdot \mathrm{L}^{-1}$ uniconazole were judged to be outliers and were not included in the exponential decay model. The average time to flower ranged from 20 to $23 \mathrm{~d}$ and was not significantly different among treatments (Table 1). Uniconazole at $8 \mathrm{mg} \cdot \mathrm{L}^{-1}$ was the only chemical and rate that reduced flower bud number. Magnitskiy et al. (2006) reported that soaking seeds of 'Quartz White' verbena in paclobutrazol at $50 \mathrm{mg} \cdot \mathrm{L}^{-1}$ for $5 \mathrm{~min}$ inhibited seedling height by $1.6 \mathrm{~cm}$ when measured $39 \mathrm{~d}$ after sowing. However, radical emergence from the media $20 \mathrm{~d}$ after seed sow was also reduced by $50 \%$.

Paclobutrazol and uniconazole were effective at inhibiting stem elongation in all species investigated, but not surprisingly, the magnitude of the height suppression depended on the chemical, rate, and plant species. For example, in argyranthemum and calibrachoa, application of uniconazole at $2 \mathrm{mg} \cdot \mathrm{L}^{-1}$ suppressed stem elongation more than paclobutrazol at $4 \mathrm{mg} \cdot \mathrm{L}^{-1}$ (statistical analysis not presented). In petunia, scaevola, and verbena, the lowest rates of 
Table 1. The effects of paclobutrazol and uniconazole liner dips on days to flower and number of flower buds in argyranthemum 'Sunlight', calibrachoa 'Callie Dark Blue', petunia 'Cascadias Vivid Red', scaevola 'Jacob's White', and verbena 'Rapunzel Red'.

\begin{tabular}{|c|c|c|c|c|c|c|}
\hline \multirow{2}{*}{$\begin{array}{l}\text { Plant growth } \\
\text { retardant }\end{array}$} & \multirow[b]{2}{*}{ Rate $\left(\mathbf{m g} \cdot \mathbf{L}^{-1}\right)^{\mathrm{z}}$} & \multicolumn{5}{|c|}{ Species } \\
\hline & & Argyranthemum & Calibrachoa & Petunia & Scaevola & Verbena \\
\hline \multicolumn{7}{|c|}{ Time to flower (d) } \\
\hline \multirow[t]{3}{*}{ Paclobutrazol } & 4.0 & $37 \mathrm{~b}$ & $32 \mathrm{a}$ & $23 \mathrm{ab}$ & $53 \mathrm{ab}$ & $20 \mathrm{a}$ \\
\hline & 8.0 & $43 \mathrm{ab}$ & $32 \mathrm{a}$ & $25 \mathrm{ab}$ & $57 \mathrm{a}$ & $21 \mathrm{a}$ \\
\hline & 16.0 & $47 \mathrm{a}$ & $30 a$ & $27 \mathrm{a}$ & $56 a$ & $21 \mathrm{a}$ \\
\hline Uniconazole & 8.0 & $47 \mathrm{a}$ & $30 \mathrm{a}$ & $24 \mathrm{ab}$ & $54 \mathrm{a}$ & $21 \mathrm{a}$ \\
\hline Significance & & $* * *$ & NS & $\star$ & $\star * *$ & NS \\
\hline \multicolumn{7}{|l|}{ Flowers (no.) } \\
\hline Control & 0 & $40 \mathrm{a}$ & $90 \mathrm{ab}$ & $24 \mathrm{a}$ & $86 a$ & $24 \mathrm{a}$ \\
\hline Paclobutrazol & 4.0 & $34 \mathrm{a}$ & $96 a$ & $19 \mathrm{ab}$ & $71 \mathrm{ab}$ & $22 \mathrm{a}$ \\
\hline Uniconazole & 8.0 & $36 a$ & $69 \mathrm{c}$ & $14 \mathrm{c}$ & $53 \mathrm{~b}$ & $12 \mathrm{~b}$ \\
\hline Significance & & NS & $* * *$ & $* * *$ & * & $* * *$ \\
\hline
\end{tabular}

${ }^{\mathrm{z}} \mathrm{l} \mathrm{mg} \cdot \mathrm{L}^{-1}=1 \mathrm{ppm}$.

'Within-column means followed by different letters are significantly different by Tukey's honestly significant difference test at $P \leq 0.05$

$\mathrm{Ns}^{*,},{ }^{* \star *}$ Nonsignificant or significant at $P \leq 0.05$ or 0.001 respectively.

paclobutrazol and uniconazole effectively controlled stem extension. Stem elongation responses in all species were statistically similar among plants treated with paclobutrazol at $8 \mathrm{mg} \cdot \mathrm{L}^{-1}$ and uniconazole at $4 \mathrm{mg} \cdot \mathrm{L}^{-1}$. Similarly, plants treated with paclobutrazol at $16 \mathrm{mg} \cdot \mathrm{L}^{-1}$ and uniconazole at $8 \mathrm{mg} \cdot \mathrm{L}^{-1}$ were also of similar height for each species investigated (statistical analysis not presented).

The chemical applications also delayed flowering time and decreased flower number in some species treated at the higher chemical rates. In all species except argyranthemum, average time to flower was similar for plants treated with paclobutrazol at $4 \mathrm{mg} \cdot \mathrm{L}^{-1}$ and uniconazole at $2 \mathrm{mg} \cdot \mathrm{L}^{-1}$, paclobutrazol at $8 \mathrm{mg} \cdot \mathrm{L}^{-1}$ and uniconazole at $4 \mathrm{mg} \cdot \mathrm{L}^{-1}$, and paclobutrazol at $16 \mathrm{mg} \cdot \mathrm{L}^{-1}$ and uniconazole at $8 \mathrm{mg} \cdot \mathrm{L}^{-1}$. For scaevola and verbena, liners dipped in uniconazole at $8 \mathrm{mg} \cdot \mathrm{L}^{-1}$ had, on average, 29 and 9 fewer flowers compared with plants treated with paclobutrazol at $16 \mathrm{mg} \cdot \mathrm{L}^{-1}$ respectively. In calibrachoa, plants treated with uniconazole at $2 \mathrm{mg} \cdot \mathrm{L}^{-1}$ had 22 fewer flowers than plants treated with paclobutrazol at $4 \mathrm{mg} \cdot \mathrm{L}^{-1}$.

The effectiveness of a liner dip at controlling stem elongation could be influenced by several environmental and cultural factors, such as duration of the dip treatment, moisture level of the media, irradiance during application, and size of plant material (Schnelle and Barrett, 2006; Schnelle et al., 2005). In our study, the medium was moderately dry at application and was allowed to absorb the PGR solution for $30 \mathrm{~s}$. Longer application durations or a lower medium moisture content could increase the volume of PGR solution absorbed and thus elicit a stronger treatment effect. Bearce and Singha (1992) reported that poinsettia cuttings rooted in foam and irrigated $36 \mathrm{~h}$ before a uniconazole dip absorbed $9.3 \mathrm{~mL}$ more solution and were $\leq 9.9 \mathrm{~cm}$ shorter than those irrigated immediately before treatment. Therefore, to reduce variability when a PGR liner dip is used for height control, a repeatable protocol is required to maintain consistency among applications. Further studies are needed to determine effective liner dip rates of paclobutrazol and uniconazole for controlling stem elongation in other bedding plant species.

\section{Conclusion}

A pretransplant liner dip application of paclobutrazol or uniconazole can be an effective strategy to control subsequent stem elongation in argyranthemum, calibrachoa, petunia, scaevola, and verbena. A liner dip PGR application before transplant can be useful when finished containers are grown that combine vigorous and less aggressive species with different requirements for PGRs. Applying a liner dip only to the aggressive species could suppress extension growth and allow time for less aggressive, nontreated species to develop. Based on our results, suggested liner dip application rates of paclobutrazol in the mid spring for growers located in the upper midwestern and northeastern United States are 4 to $6 \mathrm{mg} \cdot \mathrm{L}^{-1}$ for petunia and scaevola, 6 to $8 \mathrm{mg} \cdot \mathrm{L}^{-1}$ for argyranthemum and calibrachoa, and 8 to $12 \mathrm{mg} \cdot \mathrm{L}^{-1}$ for verbena. For uniconazole, growers could begin with liner dip application rates of 1 to $2 \mathrm{mg} \cdot \mathrm{L}^{-1}$ for petunia, 2 to $4 \mathrm{mg} \cdot \mathrm{L}^{-1}$ for calibrachoa, and 3 to $4 \mathrm{mg} \cdot \mathrm{L}^{-1}$ for argyranthemum, scaevola, and verbena. A paclobutrazol or uniconazole liner dip can delay flowering by 6 to $13 \mathrm{~d}$ in argyranthemum, petunia, and scaevola. Higher chemical rates may be needed for desirable height control later in the spring or in locations with a higher growing temperature and light intensity. Growers 


\section{Research Reports}

should perform their own trials to determine the best liner dip application rates for their greenhouse environment and individual bedding plant species.

\section{Literature cited}

Barrett, J. 1999. Chemical growth regulators, p. 94-104. In: C.A. Buck, S.A. Carver, M.L. Gaston, P.S. Konjoian, L.A. Kunkle, and M.F. Wilt (eds.). Tips on growing bedding plants. 4th ed. Ohio Florists' Assn. Serv. Columbus, Ohio.

Bearce, B.C. and S. Singha. 1992. Response of poinsettia to preplant rootzone soaks in uniconazole. HortScience 27:1228.
Davis, T.D., G.L. Steffens, and N. Sankhla. 1988. Triazole plant growth regulators. Hort. Rev. 10:63-105.

Gibson, J.L., T.J. Cavins, L. Greer, B.E. Whipker, and J.M. Dole. 2003. Efficacy of plant growth regulators on the growth of Argyranthemum frutescens 'Comet Pink'. Acta Hort. 624:213-216.

Krug, B.A., B.E. Whipker, and I. McCall. 2005. Flurprimidol is effective at controlling height of 'Star Gazer' oriental lily. HortTechnology 15:373-376.

Krug, B.A., B.E. Whipker, and I. McCall. 2006. Hyacinth height control using preplant bulb soaks of flurprimidol. HortTechnology 16:370-375.

Latimer, J. and V. Groover. 2005. PGR liner dips on herbaceous perennials.
Greenhouse Product News 15(9):3844.

Magnitskiy, S.V., C.C. Pasian, M.A. Bennett, and J.D. Metzger. 2006. Controlling plug height of Verbena, Celosia, and Pansy by treating seeds with paclobutrazol. HortScience 41:158-161.

Schnelle, R. and J. Barrett. 2006. Reducing PGR liner dip variables. Greenhouse Product News 16(7):70-72.

Schnelle, R., C. Cerveny, and J. Barrett. 2005. Factors affecting PGR liner dips. Greenhouse Product News 15(7):20-25, 106-107.

Starman, T.W. and M.S. Williams. 2000. Growth retardants affect growth and flowering of scaevola. HortScience 35:36-38. 